\title{
Fryderyk Chopin in Polish Literature
}

\section{[Fryderyk Chopin v polské literatuře]}

\author{
Libor Martinek
}

\section{DOI: 10.18355/XL.2015.08.02.85-98}

\section{Abstrakt}

Proslulý polský skladatel Fryderyk Chopin je s českými zeměmi spojen několika návštěvami (Karlovy Vary, Praha, Děčín, Teplice v Čechách, Mariánské Lázně), při kterých prožil št’astné chvíle shledání se svou rodinou, žijící v ruském záboru, poznal svou velkou lásku Marii Wodzińskou, která zůstala nenaplněna, v Praze se setkal s českými obrozenci (mj. s Václavem Hankou) a s významnými skladateli té doby; ve Vídni, centru habsburské monarchie, navázal četné další kontakty s českými skladateli a srdečné přátelství s houslistou Josefem Slavíkem; navštívil také české zámky, kde koncertoval, zejména srdečně byl vítán $\mathrm{v}$ Děčíně. Rovněž jeho učitelé hudby ve Varšavě byli českého původu. Četné vazby skladatele na české země vedly u nás i k založení Společnosti Fryderyka Chopina a k pravidelnému mezinárodnímu festivalu v Mariánských Lázních, dokonce k muzikologickým sympoziím. Mnohé pozoruhodné skutečnosti spojené s pobyty a prožitky Chopina v českých zemích nebo na území rakouské monarchie, obecně i jeho pozoruhodný, romantický život, vrozený demokratismus ve smýšlení, osobní vlastnosti, charakter i umělecké založení, to vše přivedlo četné české spisovatele, jak básníky, tak i prozaiky, ale i literární historiky, muzikology a výkonné hudební umělce k vyjádření vztahu k Chopinovi, jeho hudbě a také ke vzniku zajímavých literárních děl; $\mathrm{z}$ nich za všechny jmenujme sbírky veršů básníků Kamila Bednáře, Jiř́ho Karena, Josefa Pávka, Oldřicha Zemka, Karly Erbové nebo soubor tří novel Vladislava Mareše. Studie se kromě pojednání o významných českých chopinianách a překladech nejvýznamnějších polských chopinian do češtiny soustřed’uje především na vztah literatury a hudby v dílech polských spisovatelů.

Klíčová slova

Fryderyk Chopin, hudba, polská literatura, beletrie, memoáry, západočeské lázně

„, Chopin není jen virtuóz, je také básník, dokáže nám předávat poezii, která žije v jeho duši. Je také skladatelem a nic se nevyrovná radosti, jakou nám dává, když usedne ke klavíru a improvizuje. Neni ani Polák, ani Francouz, ani Nèmec; pocházi z kraje Mozarta, Raffaela, Goetha: jeho skutečnou vlastí je kouzelné království poezie. “

(Heinrich Heine)

Osobnost polského romantického skladatele Fryderyka Chopina, jehož dvousté výročí narození jsme si připomněli v roce 2010, vzbuzovala zájem nejen muzikologů, historiků, životopisců a dalších odborníků, ale také spisovatelů jak v Polsku, tak ve světě. Byli to jak jeho vrstevníci, vzpomeňme Cypriana Kamila Norwida, jenž napsal poemu Chopinův klavír inspirovanou skutečnou událostí roku 1863 ve Varšavě, kdy ruští vojáci vyhodili Chopinův nástroj z okna, tak autoři mnohem mladší.

Ostatně Chopin sám jevil zájem o literaturu a soudobé umění vůbec, $\mathrm{k}$ jeho nejvýznamnějším přátelům patřili skladatelé Hector Berlioz a Ferenc Liszt, malíŕ Eugéne Delacroix, básník Heinrich Heine nebo prozaik Honoré de Balzac. S emancipovanou spisovatelkou George Sand také nějakou dobu žil, později se tento vztah stal námětem k četným literárním ztvárněním. 
Hned v úvodu našeho př́ispěvku je třeba zrekapitulovat Chopinovy návštěvy v Čechách a připomenout skutečnost, že Chopin během svého života navštívil české země celkem čtyřikrát; pobýval v Praze, v Teplicích, v Děčíně, ale št’astné chvíle prožil zejména v Karlových Varech, kam prijiel za svou rodinou v roce 1835, a o rok později v Mariánských Lázních, aby navštívil rodinu Wodzińských. Několik českých spisovatelů se proto věnovalo beletrizaci nebo odbornému historickému zpracování těchto pobytů, o čemž podrobněji pojednáváme knize Fryderyk Chopin v české literatuře (Martinek, 2013). ${ }^{1} \mathrm{~V}$ Praze se poprvé objevil se skupinou svých přátel při cestě z Vídně do Drážd'an v roce 1829, ubytoval se v hotelu U Černého koně v místě dnešní České národní banky, kde je také umístěna Chopinova pamětní deska. Po příjezdu 21. srpna chtěl hned po obědě navštívit Václava Hanku v Muzeu Království českého, ale zdržel se prohlídkou katedrály sv. Víta, kde ho zaujal náhrobek Jana Nepomuckého a kaple sv. Václava. Prahu shlédl z hradního návrší a popsal ji v dopise rodičům: „Město je celkem pěkné, jak je z hradního nádvoři vidět, velké, starobylé, kdysi bohaté. “ Archiváře muzea v úřadě zmeškal. Hanku posléze našel spolu s přáteli, juristou Ignacym Maciejowským a medikem Alfonsem Brandtem. Hanka znal osobně Chopinova kmotra, profesora politické ekonomie na varšavské univerzitě Fryderyka Skarbka. Maciejowski měl pro Hanku doporučující dopis a odvděčil se básní, kterou Chopin zhudebnil jako Mazur G dur v lydickém modu. Objevitele údajně starobylého Rukopisu královédvorského mohla tato báseň potěšit, protože je v ní oslavován jako ten, jenž „,bratrského lidu písně / vyrval z časů zhoubné plísně“, tedy za objev Rukopisu a za buditelskou činnost; báseň končí česko-polskou zdravicí: , Syna zdraví české země / nadviselských Slovan plémě“. Mazurek byl vepsán do pamětní knihy, kam Brandt ještě dopsal dvojverší z Konrada Wallenroda Adama Mickiewicze, ${ }^{2}$ jehož vpis do památníku jim Hanka ukázal. ${ }^{3}$

Na druhou návštěvu se pak Chopin vypravil sám. Patřila mannheimskému rodáku Friedrichu Wilhelmu Pixisovi, jenž po uměleckých cestách Evropou zakotvil v Praze, kde na hudební konzervatoři založil houslové oddělení. Pixisovým žákem byl i slavný český houslista Josef Slavík, jehož Chopin poznal ve Vídni. Chopinovým učitelem klavíru ve Varšavě byl Čech Vojtěch Živný, rodák ze Mšena u Mělníka, jeho druhý učitel hry na klavír a varhany Václav Vilém Würfel, jenž Chopina učil technice klavírního stylu brillant, se narodil v českých Plaňanech (poblíž Kolína). Také ředitel varšavské konzervatoře, ze Slezska pocházející Polák Josef Elsner znal dobře české kulturní poměry, jelikož po určitou dobu profesně působil v Brně. Chopin byl díky Elsnerovým doporučujícím dopisům během svého pobytu ve Vídni v roce 1829 představen českému skladateli Vojtěchu Jírovcovi a rakouskému klavírnímu pedagogovi Carlu Czernymu.

Chopin podle pověsti věnoval v kladských Dušníkách dva koncerty ve prospěch sirotků po českém dělníkovi - kovári z nedaleké dílny (tato událost byla časem dokonce barvotiskově zabarvená; mladý Chopin se měl údajně zamilovat do zchudlé, leč krásné české vdovy jménem Libuše). Kdežto polský chopinolog prof. Kazimierz Maciąg na základě studia archiválií dospěl k názoru, že nešlo o proletáře, ale pravděpodobně o lázeňského hosta českého původu, po jehož náhlém úmrtí nezbyly vdově $\mathrm{s}$ dětmi a služebnictvem peníze na návrat domů. Koncerty se v roce 1826 nepochybně uskutečnily, umělecky byly úspěšné, ale zdali pomohly vdově, aby se vyrovnala s obtížnou finanční situací, v tom se prameny rozcházejí.

\footnotetext{
${ }^{1}$ Úvodní část článku z ní taktéž vychází v podstatě nezměněné textové podobě.

${ }^{2} \mathrm{~K}$ inspiracím Chopina dílem Mickiewicze srov. Tarasti 1992: 401-426.

${ }^{3}$ Co se týče Chopinova pobytu v Praze, odkazujeme se na dostupnou literaturu (Simonides, 1953).
} 
Vrat'me se však do Prahy, kde Chopin během návštěvy u Pixise projevil přání seznámit se s drážd’anským skladatelem Augustem Klengelem, jenž tou dobou pobýval v Praze. Autor Kánonů a fug ve všech durových a mollových tóninách se vskutku toho dne dostavil a své klavírní umění předváděl dvě hodiny, aniž by ho napadlo vybídnout mladého Poláka, aby také něco zahrál. Nicméně od Klengela, jenž se těšit určité lokální proslulosti, dostal doporučující dopis pro Drážd’any, který se Fryderykovi nepochybně hodil při jeho další zastávce v Sasku. Chopin ostatně v Praze ani nemínil koncertovat, když si toto provinční město habsburské monarchie dovolilo před ním zkritizovat Paganiniho vystoupení, a celkově byl zdejší předsmetanovský hudební život značně konzervativní.

$\mathrm{Na}$ cestě z Prahy Chopin navštívil Teplice, kde se setkal se svým přítelem Ludvíkem Lempickým a zavítal také na zámek hraběte Clary-Aldringena; z této návštěvy se zachoval dopis o jeho hře ve společnosti i záznam v deníku Eufemie Claryové. Teplice v Čechách, přezdívané Malá Paříž, poté navštívil ještě jednou roku 1835 při cestě z Karlových Varů do Děčína.

Podruhé si Chopin v Praze krátce odpočinul na cestě z Varšavy do Vídně opět v hotelu U Černého koně 20. a 21. listopadu 1830.

V roce 1835 prrijela Chopinova rodina do tehdejšího Karlsbadu, což bylo př́ležitostí k setkání s Fryderykem, tehdy již z vlastní vůle polským emigrantem, na půdě pro Poláky neutrální. Rodiče se sestrami byli ubytováni v hotelu U Zlaté růže, společně zde všichni strávili tři týdny. Chopin pak s rodinou odjel do Děčína na pozvání hraběte Thuna-Hohensteina, jehož děti vyučoval v Paříži, a do deníku jeho dcery vepsal Velký brilantní valčík As dur Op. 34, č. 1 „Děčínský“. Odtud se po smutném loučení s blízkými odebral do Drážd’an. Nevelká náhoda tomu chtěla, aby se tam setkal s rodinou Wodzińských, kterou již znal z Varšavy; synové Wodzińských byli chovanci penzionátu Chopinova otce Mikołaje (Nicolase). Wodzińští s výjimkou otce, jenž spravoval rozsáhlé statky v Polsku, pobývali několik let v Ženevě, odkud se přes Drážd’any, kde tehdy žila početná polská kolonie, vraceli do vlasti. Za pět let od doby, kdy je Fryderyk viděl naposledy, starší ze tří dcer, Marie, vyzrála v dívku, která se ve svých šestnácti letech projevovala jako obdařená několika uměleckými talenty. O rok později, v létě roku 1836, Teresa Wodzińská s dcerami Marií, Józefou a Tereniou i s vychovatelkou slečnou Malletovou přijely do tehdejšího Marienbadu. Ubytovaly se 9 . července v penzionu později známém jako dům U Bílé labutě, kam za nimi prrijel Chopin o třináct dní později (28. července) na návštěvu. Z té doby pochází i proslulý Mariin akvarel - Chopinův portrét. Společně zde strávili měsíc, pak odcestovali do Drážd’an. Fryderyk Chopin věnoval Marii Wodzińské do zápisníku dvě své etudy As dur a f moll. Fryderyk prožil silné citové vzplanutí k nevšední dívce; po návratu do Drážd’an snad došlo mezi nimi $\mathrm{k}$ tajným zásnubám, o nichž věděla Mariina matka Teresa. Vztah mladé dvojice zůstal z různých př́čin, jejichž podrobný rozbor není naším cílem, ale různým způsobem byl interpretován skladatelovými životopisci, nenaplněn. Chopinovo důležité milostné vzplanutí vyhaslo po dvou letech skladatelovy korespondence s Marií a její matkou Teresou, kterou uložil v balíčku vlastnoručně nadepsaném Moja bieda („Moje hoře“). Později se vztah Fryderyka a Marie stal - dá se říci - vděčným tématem řady literárních zpracování. Kromě Eleonory Ziemięcké, která v létě roku 1836 rovněž pobývala v Marienbadu a jíž vděčíme za přepjaté vyprávění o společných plánech a snech obou mladých lidí (Ziemiecka, 1861, 1974), se vztah Fryderyka a Marie stal inspirací pro další polské i české spisovatele (dílům těch druhých se v článku věnujeme jen stručně, odkazuji proto na již zmíněnou knihu Fryderyk Chopin v české literatuře).

K paradokumentárním textům, které se týkají Chopina a vydaným na české půdě, patř́ textová koláž Osvalda Klappera Chopin v Čechách 1835 (1975) vydaná u př́ležitosti 165 . výročí skladatelova narození. Jak je patrné z letopočtu umístěného 
v názvu díla, jeho obsah se týká Chopinova pobytu v Karlových Varech a Děčíně. Známý výtvarník a grafik, jenž je také autorem chopinovských karikatur, do ní umístil úryvky ze slovenského vydání knihy Chopin (1973) Jarosława Iwaszkiewicze, z dopisů skladatelova otce Mikołaje Chopina jeho zeti Konstantymu Jędrzejewiczovi z Karlových Varů (datovaný 16. srpna 1835) a rodině do Varšavy (ze stejného dne), z dopisu Fryderyka Chopina rodině z Edinburghu (19. srpna 1848) i část zmíněného Valčíku As dur, který skladatel zkomponoval na zámku Thuna-Hohensteina v Děčíně a dedikoval jeho dceři Josefẽ (15. září 1835).

Zůstaneme-li u knižně vydané korespondence, Jaroslav Simonides přeložil z francouzského originálu proslulý dopis George Sand jejímu i Chopinovu důvěrnému př́teli Wojciechu Grzymałovi (z konce května 1838) pod titulem Psaní o lásce (1983). Významným epistolografickým doplněním do českých chopinian byl svazek Milostná sonáta - G. Sand a F. Chopin v dopisech (1989), jehož editorkou i překladatelkou byla Milena Tomášková.

Pokud jde o edice poezie s chopinovskou tematikou, výběr z básní českých a polských autorů o Chopinovi v Mariánských Lázních Zde zní ozvěna jeho tónů (1983) sestavil a připravil k vydání také Osvald Klapper. Najdeme v něm básně Františka Kropáče (Improvizace v Mariánských Lázních), Oldřicha Zemka (Maria), Jiř́ho Karena (Chopin v Mariánských Lázních s podtitulem Maria Wodzińská), Kamila Bednáře (úryvek z poemy Chopin v Mariánských Lázních) a také překlady z polské poezie - výňatek $\mathrm{z}$ Chopinova klavíru Cypriana Norwida v překladu Jana Pilaře a báseň Chopinova polonéza Marie Konopnické v translaci Olgy Neveršilové; báseň Konopnické je významná také tím, že ji autorka vepsala do pamětní knihy v den odhalení pamětní desky na Chopinově domě v Mariánských Lázních 31. července 1902 .

Kromě zmíněných básníků Oldřicha Zemka, autora sbírky Chopinovské akordy (1967), Jiřího Karena, jenž napsal sbírku Hledání modrého tónu (1979) a Kamila Bednáře jako autora poemy Chopin v Mariánských Lázních (1961), později, v roce 1981 vydanou pod titulem Fryderyk a Marianna (Chopin v Mariánských Lázních), je třeba připomenout sbírku Chopiniana (1976) Josefa Pávka a dvojjazyčnou, česko-polskou sbírku básnických epištol Karly Erbové Již nikdy nedovolím požáru - Już nigdy pożarem mi nie płonąć (2003), která se specificky věnuje vztahu Chopina a George Sand. Přehled českých básnických chopinian pak již jen doplňuje báseň Františka Branislava Chopinův stesk; tato v letní atmosfére laděná báseň vyšla v Branislavově sbírce s hudebním titulem Divertimento a kantiléna (1964). Co se týče prózy, jak už napovídá titul novelky Růže pro Fryderyka (1993) Vladislava Mareše, autor se zabývá pobytem Chopina v Mariánských Lázních a jeho nenaplněnou láskou k Marii Wodzińské. Posmrtně vyšel Marešův biografický román Brilantní valčík, Návštěvy Fryderyka Chopina v Čechách (2000).

Z uvedeného výčtu je patrné, že Chopinovy pobyty v Čechách inspirovaly několik českých spisovatelů $\mathrm{k}$ vytvoření více či méně povedených literárních děl. V další části př́spěvku se pokusíme odpovědět na otázku, zdali tyto ,české“ epizody z Chopinova života, spojené s pobytem v západočeských lázních i jinde (v Praze, Teplicích, Děčíně), byly důležité i pro polské spisovatele, popř́ípadě se pro ně staly významné některé osobnosti spjaté svým původem s Čechami a vstupující nějakým způsobem do skladatelova života. Zároveň si kladu za cíl odlišit v polsky psaných beletristických pracích literární fikci, pověst, legendu či mýtus od historické pravdy v kontextu Chopinových pobytů v Čechách. Chci se rovněž zamyslet nad tím, jakým způsobem byly tyto epizody $\mathrm{z}$ umělcova života beletrizovány, jakým literárním strategiím byly podřizeny, poprrípadě co bylo jejich motivací a čím byly podmíněny. 
Čeští čtenáři mají k dispozici překlad životopisné knihy Chopin (1955) Jarosława Iwaszkiewicze (1894 - 1980), který vyšel pod titulem Fryderyk Chopin (1810 - 1849) (1957). Příznačné přitom je, že zmínění čeští spisovatelé, zejména Oldřich Zemek a Kamil Bednář, museli být s touto knihou dobře obeznámeni. $\mathrm{Z}$ doslovu Jaroslava Simonidese k Bednářově sbírce Fryderyk a Marianna (Chopin v Mariánských Lázních) (1981) se dozvídáme, že básník „překládal verše citované $v$ chopinovské monografii Jarosława Iwaszkiewicze a s jeho básnickou spoluprací vyšly $i$ Chopinovy listy rodině a přátelìm. ${ }^{l} V$ této knize ho zvlášt’ zaujala kapitola o vztahu polského skladatele k Čechám. Prostudoval si známá fakta a po několikaměsičnim hledáni cesty ke ztvárněni syžetu napsal pak - už ve velmi krátké době - cyklus Chopin v Mariánských Lázních" (Simonides, 1981).

O návštěvě Chopina v Praze u Václava Hanky nás zpravuje rovněž polský prozaik Tadeusz Łopalewski v životopisném románu Fryderyk (1975) ${ }^{2}$, v němž zachycuje především Chopinovo dětství a mládí. Vyprávění, určené zejména dětem a mládeži, končí porážkou polského listopadového povstání v r. 1830 proti ruským okupantům a Chopinovým odjezdem za hranice. V románu nemohla chybět ani „legenda o Libuši“, tedy př́íhoda s náhle osiřelou (nikoli tedy ovdovělou) mladou Češkou během Chopinova pobytu v Dušníkách ${ }^{3}$ roku 1826. Tato pověst je vylíčena shodně s obrazem, jenž v polské literatuře zdomácněl v druhé polovině 19. století. Fryderyk se do modrooké Libuše zamiluje, nejprve ji navštěvuje se svou matkou, která sleduje nešt’astnou dívku s neskrývaným podezřením, pak koncertuje ve prospěch finanční sbírky na dívku a její čtyři sourozence po smrti otce dětí, dělníka v nedaleké slévárně. Polský chopinolog Kazimierz Maciąg obrací pozornost na zajímavý moment $\mathrm{v}$ knize Łopalewského, kterým je idylická scéna, odehrávající se mezi zamilovanými během jejich rozloučení. (Maciag, 2010: 307.) Umělec se setkává s Libuší před jejím lázeňským domem, odkud jdou společně ke studni:

„Dziewczyna postawiła kubet na cembrowinie.

- Muszę się napić - rzekta. Dzień jest goracy.

- Właśnie o tym samym pomyślatem! - zawolat Fryderyk.

- Proszę.

- Nie. Możemy jednocześnie. Ja z tej strony, a pani z drugiej.

Zanurzyli oboje usta w klarownej, chtodnej wodzie. Czoła ich zetkty się. Pili wolno wpatrzeni $w$ swoje odbicie, rozbawione spojrzenia spotkaty się jak $w$ lustrze. Fryderyk unióst glowe $i$ odetchnąt głęboko. "4 (Łopalewski, 1975: 128.)

${ }^{1}$ Simonides měl nepochybně na mysli knihu Fryderyk Chopin, Listy rodině a př́telům (1961).

${ }^{2}$ Český překlad: Tadeusz Łopalewski, Fryderyk. Přel. Josef Zumr. Praha: Albatros, 1986.

${ }^{3}$ Duszniki-Zdrój je lázeňské město $\mathrm{v}$ jihozápadním Polsku, $\mathrm{v}$ Dolnoslezském vojvodství, na řece Kladská Bystřice. Město se nachází v západním Kladsku, blízko česko-polské hranice. (Cit. podle Wikipedie <http://cs.wikipedia.org/wiki/Duszniki$\mathrm{Zdr} \% \mathrm{C} 3 \% \mathrm{~B} 3 \mathrm{j} .>)$

4 „Dívka postavila vědro na roubení.

»Musím se napít, « řekla. »Je dnes horko.«

»Zrovna jsem na to taky myslel!« zvolal Fryderyk.

»Prosím.«

»Ne. Můžeme společně. Já z téhle strany a vy z druhé.«

89

XLinguae Journal, Volume 8 Issue 2, April 2015, ISSN 1337-8384 
Pití z jedné nádoby je bohaté na literární evokace a nemohlo zůstat bez fabulačních důsledků. Autor poskytuje čtenáři naději na další pokračování citového vzplanutí obou mladých lidí. Libuše odjíždí do Prahy, ale Fryderyka informuje, kde by ji mohl najít, kdyby město navštívil během svých uměleckých cest. Autor při pozdějším Chopinově pobytu v Praze (během jeho návratu z Vídně v roce 1829) před odjezdem z města nechává pianistu si vzpomenout na svou lásku, kterou prožil před několika lety: „I dopiero przy wsiadaniu do dyliżansu przypomniat sobie Fryderyk, że mógł by odnaleźć i zobaczyć swa dawna sympatię z Dusznik, mita Libuszę. Zupelnie o niej zapomniat. - Pewnie wyszła za mąż $i$ dziatki niańczy - westchną $w$ duchu. - To już kilka lat uptynęto... od tamtej dziecinady mojej" "1 (Łopalewski, 1975: 193). Tadeusz Łopalewski tedy využívá legendu o Libuši k rozvíjení některých detailů v epizodách $\mathrm{z}$ Chopinova životopisu k uměleckým cílům, zejména $\mathrm{k}$ vytvoření co nejzajímavějšího obrazu slavného polského umělce v knize určené především mládeži, jejímž hlavním cílem bylo zdůraznit polský rodokmen Fryderyka i jeho hudby.

Stejnou legendu o české dívce Libuši využívá Janina Siwkowska (1906 1981) v knize pro mládež Tam, gdzie Chopin chodził na pół czarnej... Stylizacje („Tam, kde Chopin chodil napůl v černém... Stylizace“; 1959) skládající se z pěti epizod ze života umělce a je zvláštní žánrovou variantou prózy, kterou autorka sama nazývá „stylizaci““. Autorským záměrem bylo stylizování textu do podoby jazyka, jakým se mluvilo v první polovině 19. století. Čtenář pak získává dojem, že čte památník psaný v době Chopinova mládí návštěvníkem tehdejších salonů a vášnivého čtenáře tisku, jenž sleduje kariéru mladého Fryderyka. (Siwkowska je dále autorkou knihy Pan Chopin opuszcza Warszawę /,Pan Chopin opouští Varšavu“/ z r. 1969, kterou už můžeme nazvat klasickým románem a výsledkem jejích podrobných studií o Chopinově rodině je třídílná práce Nokturn czyli rodzina Fryderyka Chopina i Warszawa w latach 1832 - 1881, /,Nokturno neboli Chopinova rodina a Varšava v letech 1832 - 1881“/ sv. 1 - 3, Warszawa 1986, 1988, 1996.) Siwkowska v kapitole o Chopinově pobytu v Dušníkách Frycek pije Reinertzką Serwatkę („Frycek pije reinertskou syrovátku“) mimo jiné cituje zmínku z Kuriera Warszawskiego („Varšavského kurýra“) o Chopinových koncertech v lázních ve prospěch několika dětí, které „,przez śmierć ojca do wód na kuracje przybylego, sierotami stały się “2 (Siwkowska, 1972: 25). Z Prahy spolu s otcem, jenž po paralyzujícím záchvatu předčasně zemřel, měly podle autorky přijet dvě děti (tedy nejmenší počet $\mathrm{z}$ oněch „několika“). Eventuální cit skladatele k mladé Češce je Siwkovskou podán velmi zdrženlivě, čtenář se dozvídá, že Fryderykovi chybí ona mladá dívka a při odjezdu „, skuteczna sita, jaka jest serc obopólne, choćby najlżejsze drgnienie, wraz z ostatnim smutnych źrenic wejrzeniem wsiadajacej $w$ dylizans pocztowy dzieweczki $-w$ tęsknoty się czucie, pustelnictwa spragnione - transfigurowata “3 (Siwkowska 1972: 32). Jak

Ponořili svá ústa do průzračné chladné vody. Jejich čela se dotkla. Pili zvolna, dívali se na svůj obraz a jejich veselé pohledy se setkávaly jako v zrcadle. Konečně Fryderyk zvedl hlavu a zhluboka si oddechl.“(Łopalewski, 1986: 114-115.)

1 „Teprve když vsedali do dostavníku, Fryderyk si vzpomněl, že mohl vyhledat a uvidět svou starou lásku z Dušníků, usměvavou Libuši. Úplně mu vypadla z paměti. Jistě se už vdala a má děti, povzdychl si v duchu. Kolik let už uběhlo od té mé dětské pošetilosti!“” (Łopalewski, 1986: 170.)

${ }^{2}$ „se po smrti otce, který se přijel léčit do lázní, staly sirotami“ (není-li uvedeno jinak, překlady z polštiny provedl autor článku).

3 „opravdová moc, jakou je jen nejmenší zachvění obou srdcí se spolu s posledním pohledem smutných očí dívenky nasedající do poštovního dostavníku přeměnila v pocit touhy, žíznící po poustevnictví“. 
již postřehl Kazimierz Maciąg, nevyskytuje se zde dívka podávající vodu lázeňským hostům, sentimentální povzdechy u studny nebo dojemná představa, poněkud následující Goethovo Utrpení mladého Werthera, jak nebohá Libuše krmí hromádku osiřelých sourozenců. (Maciag, 2010: 317.) Kdyby kniha Siwkowské nevyšla poprvé $\mathrm{v}$ roce 1959, ale o dvacet nebo třicet let později, mohli bychom ji označit za částečně postmoderní dílo, nebot' vědomě pracuje s možností vícevrstvové čtenářské recepce (chybí jí však výrazná postmoderní ironie a sarkasmus). Jak si všimla dobová kritika, díky celé řadě postav a událostí v ní hudebníci a muzikologové najdou nemálo zajímavého materiálu, historikové se rádi prohrabou v archivech lidských vzpomínek, sociologové zde mají látku k dobovému společenskému životu, historikové umění nebo literární historikové galerii pozoruhodných lidských typů a obyčejný čtenář se pobaví naivními príhodami či humornými situacemi a poté pohlédne na varšavské ulice tak, jakoby si prohlížel obrazy staré Varšavy na Canelettových obrazech. (Sierpinski, 1959: 1424-1425.)

Nyní obrat'me pozornost $\mathrm{k}$ regionu západočeských lázní a pobytům Chopina a jemu blízkých osob v nich.

Maria Kuncewiczowa (1899 - 1989) je autorkou několika prozaických prací navazujících na biografii Fryderyka Chopina. ${ }^{1}$ Pro nás je významný Kurgast Marienbadzki („Marienbadský lázeňský host /resp. Mariánskolázeňský host/“; 1932), což je stručný, prozaický třídílný obraz, opírající se o historii lásky Chopina k Marii Wodzińské. Skladatel je nepochybně nejdůležitějším a v podstatě jediným hrdinou tohoto díla, které můžeme s ohledem na jednolitost tématu nazvat novelou skládající se ze tří epizod - mariánskolázeňské, drážd’anské a pařížské. Pro nás je nejzajímavější první, svým charakterem idylická epizoda, ve které zamilovaní pijí vodu z pramene, žertují a poslouchají lázeňský orchestr. Chopin koncertuje v hospodě U Bílé labutě, u níž se zastavují kolemjdoucí lázeňští hosté, aby si poslechli hudbu. Také Fryderykova nemoc ještě představuje nevinný žert. „Fryderyk wyjmowat chusteczke $i$ wdziecznie minodując - kaszlat “2 (Kuncewiczowa, 1983: 19). Ve třetí, pařížské části novely zoufalý Fryderyk při vzpomínce na svou nenaplněnou lásku k Marii chodí po pokoji se džbánkem v ruce, který si přivezl právě z Mariánských Lázní.

Kuncewiczowa představuje Chopina nikoli jako romantického umělce, ale především jako člověka, který dramatickým způsobem proživá svou existenci. Pro autorku novely je pravda o nemoci skladatele zajímavější než údajná pravda o uměleckých dilematech. Člověk a jeho život jsou v díle důležitější než ideje.

Spisovatel Juliusz Kaden-Bandrowski (1885 - 1944) v mládí studoval hru na klavír ve Lvově, Krakově, Lipsku i Bruselu. Studia ukončil s vyznamenáním, ale po těžkém úrazu ruky se musel rozloučit s hudební kariérou. O Chopina se KadenBandrowski zajímal poměrně intenzivně, jak o tom svědčí i jeho články, referáty nebo eseje v tisku. ${ }^{3}$ V knize Życie Chopina („Chopinův život“; 1938) je skladatelův životopis využit především k dalším úvahám na téma fenoménu jeho hudby. Ve svém

${ }^{1}$ Maria Kuncewiczowa je mj. autorkou črty Miłość Chopina („Chopinova láska“), jejímž tématem je skladatelův cit, kterým obdařoval Konstantinu Gładkowskou, o několik měsíců od něj mladší studentkou zpěvu varšavské konzervatoře. (Kuncewiczowa, 1937: 7.)

${ }^{2}$ „Fryderyk vytahoval kapesník a s legračním výrazem kašlal.“

3 Je jich zhruba šestnáct, některé jsou zaměřené na Chopinovo klavírní umění, jeho diaristiku $\mathrm{z}$ dětství, jiné na místa nebo významné osoby spojené s umělcovým životem, popřípadě jde o relace $\mathrm{z}$ chopinovských mezinárodních klavírních soutěží. (Viz: <http://pl.chopin.nifc.pl/chopin/persons/bibliography/id/2507>). 
díle se Kaden-Bandrowski zabývá jak předemigračním, tak emigračním obdobím Chopinova života, ale z hlediska svého literárního záměru intencionálně pomíjí některé události ze skladatelovy biografie. Namísto toho ukazuje Chopina jako výjimečnou, snad až nadpřirozenou, zázračnou osobnost. Fryderyk jako hudebním talentem podivuhodně obdařené dítě je umělecky „spasen“ již v dětském věku. Chopina dokonce označuje za Koperníka klavíru, za vynálezce, který odhalil podstatu zvuku klaviatury, oživil ji a obdařil ji pohybem, jenž je jí vlastní. Kaden-Bandrowski dokonce pomíjí různé pověsti a fámy spojené s Chopinem, včetně romance s Konstantinou Gładkowskou, které by mohly narušit hrdinský obraz klavírního virtuóza a skladatele. Také Fryderykův rozchod s Marií Wodzińskou měl vyplývat z obav rodiny snoubenky o zdraví umělce, což autor ličć humoristicky až hrůzostrašně: „Ze Stużewa, tu spod Warszawy, śledza aż tam, w Paryżu, czy zalecenia spetnia, opukać by go chcieli, pluca do ręki wziać i jak robórkę lub kaszmirski dywanik przejrzeć, czy nie ma dziur? "1 (Kaden-Bandrowski, 1938: 65). Kazimierz Maciąg má za to, že Kaden-Bandrowski „stworzyt konterfekt genialnego artysty, który jednak wydaje się schematyczny i pozbawiony znamion indywidualności. (...) z tego też wzgłędu wszystkie miłości bohatera ksiązki wydaja sie "papierowe", przeżywane tylko

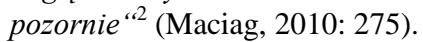

Ke konci druhé světové války zveřejnila polská muzikoložka Zofia Lissa (1908 - 1980) brožurku Fryderyk Szopen, kterou vydal Svaz vlastenců Polska v SSSR. Publikace byla obdařena charakteristickým podtitulem Krótki życiorys („Stručný životopis“). Knížka měla uvést osobnost skladatele do paradigmatu hodnot deklarovaných v nově vznikajícím socialistickém státě - Polské lidové republice. Modelový čtenář textu musel být značně nekritický, bez větší znalosti dějin umění; kniha byla určena především pro vojáky „Ludowego“ Wojska Polskiego (Polské „lidové“ armády), vstupující na území vlasti. Jejím posláním bylo motivovat osvoboditele k válce s hitlerovskými okupanty: „Dziś nad krajem Chopina zawisła czarna chmura. Brutalna noga niemieckiego żołdaka depce ziemię polska; pięść hitlerowska dławi polska mowę, polska pieśń, zwierzęca myśl gestapowca wysila się nad sposobami wyniszczenia, wymordowania narodu polskiego "3 (Lissa, 1944: 31). Autorka připomíná ztráty, které utrpěla polská chopinologie během války - bylo zničeno muzeum v Chopinově rodišti Železné Voli, zbořen Chopinův pomník ve Varšavě a upozorňuje i na skutečnost, že během německé okupace Polska platil zákaz hraní Chopinovy hudby. Z hlediska třídního pohledu bylo zdůrazněno nízké sociální postavení rodiny budoucího skladatele, Fryderyk se během studií setkává se členy varšavských vlasteneckých společností, kteři udržují spojení s ruskými děkabristy, přátelí se s pokrokově myslící mládeží, pokrokově je rovněž vychováván doma, nebot' jeho otec Mikołaj je vášnivým čtenářem Voltairových děl atd.

Jak se domnívá Kazimierz Maciąg, autorka zmíněné brožury třídně interpretuje dokonce Chopinovy milostné pletky. Čtenář se nedozví téměř nic o peripetiích s jeho láskou Marií Wodzińskou, ale místo toho si přečte diagnózu, že

${ }^{1}$ „Ze Służewa, hned pod Varšavou, sledují až tam, v Paříži, jestli dá na jejich rady, chtěli by ho ot’ukat, plíce vzít do ruky a prohlédnout jako výšivku nebo kobereček z kašmíru, jestli v nich nejsou díry?““

2 ,vytvořil portrét geniálního umělce, který však působí schematicky a postrádá jakékoli známky individuality. (...) z tohoto důvodu všechny lásky hrdiny vypadají »jako na papíře« a jsou prožívané jenom zdánlivě."

3 „Dnes nad Chopinovou zemí visí černý mrak. Brutální noha německého žoldáka dupe po polské zemi; hitlerovská pěst dusí polskou řeč, polskou píseň, zvířecí mysl gestapáka usiluje zničit, vyvraždit polský národ.“ 
skladatel byl jako budoucí ženich odmítnut hrdým aristokratem Wodzińským. (Maciag, 2010: 371.) V knize je vícero faktografických nebo interpretačních lapsů motivovaných čistě ideologicky a při jejím psaní byly Lissou užity literární strategie vycházející ze vzoru socialistického realismu.

Pro autora tohoto článku byla existence tendenční brožurky významné polské muzikoložky značným překvapením, nebot' již jako student hudební vědy a výchovy na PdF UP v Olomouci znal její, z hlediska myšlení o hudbě inspirující, v českém překladu vydaný soubor prací z let 1968 - 1973 Nové studie z hudební estetiky (1982; Nowe szkice z estetyki muzycznej, 1975), v níž se názory, myšlenky a ideje Zofie Lissé vzdalují metodologickým postupům opírajícím se o estetickofilozofické koncepce marxistické ideologie a spíše se blíží recepční estetice a fenomenologii (přitom polemizuje s pojetím ontologie hudebního uměleckého díla $\mathrm{v}$ myšlení polského fenomenologa Romana Ingardena), popřípadě modernějším hudebně-sociologickým pojetím a nověji sbližuje muzikologii s kulturní antropologií. (Dodejme, že Zofia Lissa v roce 1960 zorganizovala v Polsku první mezinárodní chopinologický kongres a je také autorkou obsáhlé knihy Studia nad twórczością Fryderyka Chopina, 1970; „Studie o tvorbě Fryderyka Chopina“.)

Po válce vychází dvoudílný román Jerzyho Broszkiewicze (1922 - 1993) o formování Chopinova talentu Kształt miłości (1950 - 1951; č. Podoba lásky, 1976), v němž autor informuje čtenáře o Fryderykově setkání s rodiči v Karlových Varech, k němuž došlo 15. srpna 1835, v kapitole Sielanka („Selanka“). Víme i z četných historických pramenů, že z Karlových Varů pak Chopin s rodinou odcestoval 6. zárí do Děčína. Odtud pokračoval do Drážd’an, zatímco rodina se vrátila přes Vratislav do Varšavy. Broszkiewicz ovšem píše o Chopinově odjezdu z Karlových Varů spolu s rodinou nejprve do Těšína, kde se pak skladatel rozloučil se svými blízkými. Avšak $\mathrm{k}$ takovému putování $\mathrm{s}$ jistotou nikdy nedošlo (cestě do Těšína nenasvědčují ani relevantní prameny, ani se nedochovalo jakékoli jiné svědectví o pobytu Fryderyka a jeho blízkých prríbuzných v Těšíně; kromě toho je málo pravděpodobné, že by si rodina chtěla prodloužit cestu z Karlových Varů do Varšavy zrovna přes Těšín). Tímto způsobem autor uvádí čtenáře v omyl, i když v př́ípadě románu Podoba lásky jde o beletrizaci umělcova životopisu a nikoliv o dokument. Pro ilustraci tohoto lapsu lze uvést několik citátů. Chopinův otec Mikołaj údajně velmi stál o to, aby se Fryderyk vrátil domů, do vlasti a syna k tomu také přemlouval, ale to by znamenalo, že by se umělec musel stát loajálním poddaným ruského cara. Přišel tedy na nápad, že by se syn měl oženit s některou dívkou, žijící v Polsku, poté by od cara získal nejprve řád jako významný umělec a pak by se mohl ucházet o šlechtický titul. Jelikož cítil, že Fryderyk s ním na to téma nechce hovořit, požádal svou ženu, aby synovi diplomaticky představila obecné schéma takového, jak se domníval, moudrého plánu. Fryderykova maminka Justyna tedy při cestě ,,z Karlsbadu do Cieszyna (odprowadzit ich do Cieszyna właśnie) poczęła go namawiać, by porzucił wreszczie samotność. Samotność niszczy człowieka - mówiła"1 (Broszkiewicz, 1967: 302). Po matčině a Fryderykově zamyšlení na téma samoty a smrti pokračuje spisovatel v těšínské anabázi Chopinovy rodiny: „Kilka ostatnich dni spędzili w Cieszynie. Dni byly smutne. Na pożegnanie [Fryderyk] bardzo wesoło powiewat chustka $i$ wolat »do

1 ,z Karlových Varů do Těšína (doprovázel je totiž až do Těšína) ho začala přemlouvat, aby konečně nechal své osamělosti. Osamělost člověka ničí - rríkala“ (Broszkiewicz, 1976: 258). 
widzenia«". [Matka] Wiedziała, że owa wesołość jest klamstwem "1 (Broszkiewicz, 1967: 304). Podle spisovatele se měl Fryderyk až teprve z Těšína odebrat do Drážd’an, kde se setkal s rodinou Wodzińských. S touto rodinou se skladatel skutečně v Drážd'anech setkal, když ke svému švagrovi Maciejovi, hraběti Wodzińskému, jenž v Drážd'anech pobýval delší dobu a byl znám mj. jako sběratel umění, přijela paní Teresa Wodzińská se svými třemi dětmi ze švýcarské Ženevy. Do Drážd’an ovšem přicestoval Fryderyk nikoli z Těšína, ale z Děčína, kde se na zámku ThunaHohensteina 14. září 1835 také rozloučil se svými nejbližšími a sám opustil Děčín o pět dní později - 19. záŕí. Z jakého důvodu si tedy Broszkiewicz vymyslel onu těšínskou anabázi Fryderyka Chopina a jeho rodiny, lze těžko určit, navíc je málo pravděpodobné, aby spisovatel, jinak dobře obeznámený s Chopinovým životopisem, jehož část se pokusil beletrizovat, tyto významné skutečnosti umělcova života neznal. K Těšínu Jerzyho Broszkiewicze, jenž po střední škole studoval hudbu na akademii ve Lvově, nepoutaly ani nějaké zvláštní, např́iklad osobní vazby, když nejprve žil ve Lvově, poté v Krakově, pak ve Varšavě a nakonec opět v Krakově. ${ }^{2}$ Určitou teorii pro záměnu měst Broszkiewiczem si přeci jen dovolíme formulovat. Děčín se německy psal Tetschen, zatímco Těšín v němčině Teschen. Byla to snad graficky blízká podoba německých názvů měst a spisovatelova nepřesná práce s německými prameny, popř́ípadě $\mathrm{s}$ již chybným překladem německého názvu města Děčína $\mathrm{z}$ němčiny do polštiny, které zavinilo jejich záměnu? To se dnes již nedozvíme.

Broszkiewicz umělecky zobrazuje také Chopinovo sblížení s Marií Wodzińskou v Mariánských Lázních. Toto vylíčení je poměrně konvenční, nicméně ukazuje na jakousi vychytralost objektu milostného zájmu mladého skladatele, tedy Marii, která předtím měla $\mathrm{v}$ Ženevě zaujmout pozornost polského romantického básníka Juliusze Słowackého a také francouzského konzula, hraběte de Montignyho. Aby Fryderyka okouzlila, využila prý jeho dvě základní charakterové vlastnosti pýchu a nesmělost. Fryderykova korespondence s Marií a její matkou Teresou, především po tajných zásnubách s Marií, které se měly uskutečnit po návratu z lázní do Drážd'an při tzv. černé hodince, byla prý již jen pokryteckým využitím v Paříži módního, a tudíž penězi oplývajícího polského umělce. (Fryderyk skutečně na žádost Wodzińských zakoupil klavír Pleyel, který byl odvezen na jejich usedlost ve Služevě a byl také prostředníkem finanční výpomoci této rodiny staršímu synovi Antonimu, který žil od roku 1835 v Paříži poměrně rozmařilým životem a v roce 1836 se nechal naverbovat k polskému dobrovolnickému pluku během občanské války ve Španělsku, kde byl raněn.) Neúspěch vztahu s Marií Wodzińskou byl podle Broszkiewicze zaviněn nikoli špatným zdravotním stavem umělce, na který bylo často poukazováno i v korespondenci adresované Fryderykovi Marií a zejména Teresou Wodzińskými, ale ve skutečnosti jeho nízkým společenským statusem. Po závažném plicním onemocnění Chopina v říjnu roku 1835 prri cestě z Lipska do Paříže přes Frankfurt nad Mohanem, kdy byl dokonce nucen zůstat po nějakou dobu u svého někdejšího žáka Adolphe Gutmana v Heidelberku, se po Varšavě navíc roznesla falešná zpráva o Chopinově úmrtí, která se pochopitelně donesla i k uším Wodzińských; tehdy již bylo Terese Wodzińské zřejmé, že umělec není vhodným kandidátem na ženicha pro její dceru a tajné zásnuby se ve skutečné nikdy nepřerodily. Broszkiewicz nicméně soudí, že Chopin ,nie byt jednak materiałem na męża panny Wodzińskiej, córki hrabiego

1 „Několik posledních dní strávili v Těšíně. Byly to smutné dny. Při loučení [Fryderyk] až př́liš vesele mával kapesníkem a volal »na shledanou«. [Matka] Věděla, že i toto veselí je lživou přetváŕkou“ (Broszkiewicz, 1976: 258).

${ }^{2}$ Jerzy Broszkiewicz, in Slovník spisovatelů. Polsko. Praha: Odeon, 1974, s. 84-85; Jerzy Broszkiewicz, Slovník polských spisovatelů. Praha: Libri, 2000, s. 105-106. 
Wincentego, który w domu, w Stużewie, kazat się stużbie tytułować per »Sa Majesté«! O tak, Fryderyk powinien byt to wcześniej zrozumieć. Sam byt - myślała Maria winien swemu nieszczęściu "1 (Broszkiewicz, 1967: 310). Kromě beletristických prací, jež se zmiňují o Chopinově pobytu v Čechách, se můžeme stručně zmínit také o polských čítankách, v nichž se objevují portréty tohoto výjimečného polského skladatele. Ve Wypisach dla klasy VII („Výpiscích pro 7. třídu“; 1962), určených polským základním školám, se objevuje povídka Mistrz i uczeń („Mistr a žák“) již zmíněného ctitele Chopinovy hudební tvorby Jerzyho Broszkiewicze. (Kubski Kubski, 1962: 59-65.) Ta zaujme skutečností, že oním Mistrem byl Fryderykův učitel hry na klavír, Čech Vojtěch Živný. Povídka je rozehrána nejen kolem vztahu učitele a mimořádně talentovaného žáka, ale zejména podává plastický obraz prostředí, v němž Fryderyk vyrůstal. (O Živném jako Chopinově učiteli klavíru se Broszkiewicz velmi pěkně rozepisuje $\mathrm{v}$ kapitolách Jediný syn, výmluvný svět a dobrák Živný a Zelená země a konec výuky poctivého dobráka Živného v již uvedeném románu Podoba lásky.) Vojtěch Živný byl také důležitou postavou povídky Własna melodia („Vlastní melodie“) polské spisovatelky pro děti a mládež Miry Jaworczakowé (1917 - 2009) otištěné v publikaci, jež sice nesloužila prímo jako čítanka pro základní školy, ale byla pomocným materiálem pro školní vzdělávání. (Jaworczakowa, 1968: 391-394.) Jaworczakowa představuje Chopinova českého učitele klavírní hry jako právě toho, kdo št’astnou náhodou objevil neslýchaný hudební talent malého Fryderyka, když zrovna vyučoval kteréhosi méně schopného chlapce v blízkém sousedství jeho rodiny.

K našemu zklamání a smutku se Chopinově pobytu v Čechách podrobněji nevěnuje žádný ze známých polských básníků, přičemž inspirace Chopinem a jeho hudbou se v polské poezii objevují poměrně často. (Pabjan, 2010: 343-378.) Výjimkou jsou jedině polští spisovatelé z českého Těšínska a Ostravska, z nichž někteří osobně navštívili západočeské lázně. Těmto v České republice trvale žijícím polsky píšícím spisovatelům, hlásícím se k polské národnosti, nebyl život Fryderyka Chopina a jeho umělecký odkaz cizí, jak o tom svědčí básně Henryka Jasiczka (1919 - 1976) Odwiedziny („Návštěva“) (Jasiczek, 1959: 11) a Pochwała życia („Chvála života“) (Jasiczek, 1952: 61), Władysława Sikory (*1933) Marienbad („Mariánské Lázně“) (SIKORA 2002: s. 32), Jana Pyszka (1925 - 2008) Chopinowskie na Zaolziu pejzaże („Chopinovské krajiny na Záolži“) (Pyszko, 1993: 23), dokonce jeden celý cyklus veršů Wilhelma Przeczka (1936 - 2006) Miasto żywej wody s podtitulem Mariánské Lázně, styczeń 1989 r. (1990). ${ }^{2}$ V Przeczkově poezii, která je přístupná i českým čtenářům (Przeczek, 1998), se západočeské lázně objevují nejčastěji, ${ }^{3}$ zatímco fantaskní próza Wiesława Adama Bergera (1926 - 1998) Marienbad (1995; č. Marienbad a jiné povídky, 1996) souvisí s tématem Chopin v Mariánských Lázních jen volně. Básník a překladatel Jan Pyszko kromě překladu již zmíněné sbírky Karly Erbové Již nikdy nedovolím požáru - Już nigdy pożarem mi nie płonąć do polštiny

${ }^{1}$ „nebyl však osobou, která by byla vhodná jako muž pro slečnu Wodzińskou, dcery hraběte Wincenta, jenž se doma, v Służewě, nechal od služebnictva titulovat per »Sa Majesté«" [franc. jeho Veličenstvo; L. M.]! Ó ano, Fryderyk to měl dříve pochopit. Sám si zavinil své neštěstí - myslela si Marie“ (Broszkiewicz, 1976: 264).

2 Wilhelm Przeczek, Dom Chopina, Drwal, Bogusławowi, Marienbad, Noc w uzdrowisku, Ciuchcia miłości, Miasto żywej wody, Ikony, Wycieczka do Franciszka (Przeczek, 1990: 59-67).

${ }^{3}$ Kromě Mariánských Lázní jsou to i Františkovy Lázně a Karlovy Vary, jak o tom vypovídá mj. obsáhlý výbor z Przeczkovy poezie Intimní bedekr (1998) vydaný v překladu do češtiny autorem tohoto článku. 
byl rovněž autorem pásma pro polské školní divadelní scény na českém Těšínsku Mały Chopin („Malý Chopin“). ${ }^{1}$

Na závěr příspěvku bychom rádi zdůraznili skutečnost, že v kontextu celého životopisu Fryderyka Chopina se nacházejí epizody a okamžiky důležité bud' více, nebo méně. $\mathrm{K}$ těm méně důležitým, ale o to literárně vděčnějším patří Fryderykovo dětství a mládí, které se stává vhodným polem ke zpracování autory literatury určené dětem a mládeži; může nás těšit, že několik osobností českého původu nějakým způsobem ovlivnilo duchovní a umělecké zrání později proslulého polského pianisty a skladatele (např. učitel klavírní hry Vojtěch Živný nebo Chopinův profesor na varšavské konzervatoři Václav Vilém Würfel), své místo v životopise umělce má i pozdější Chopinovo prátelství s českým houslistou Josefem Slavíkem. V Chopinově biografii druhořadý, leč naplněný štěstím ze setkání dobrovolného emigranta s rodinou, je skladatelův pobyt v Karlových Varech. K tomu připočtěme Fryderykův milostný cit k Marii Wodzińské, jenž se rozvijí během jejich společného pobytu $\mathrm{v}$ Mariánských Lázních. Podobně je tomu s legendárními událostmi ze života Fryderyka Chopina, ke kterým patři jeho údajné zalíbení v náhle osiřelé (podle jedné verze pověsti) či ovdovělé (podle druhé verze) Češce Libuši v Dušníkách. V těchto kladských lázních Chopin sice koncertoval, ale ve skutečnosti na podporu konkrétně nejmenované české vdovy poté, co jí náhle zesnul chot' a ona zůstala bez prostředků na návrat domů. Výčet polských spisovatelů, kteři se inspirovali Chopinem, není zcela samozřejmě a pochopitelně - v našem článku úplný (syntetizujícím způsobem je dosud nejlépe zpracován ve zmíněné knize profesora Univerzity v Rzeszowě Kazimierze Maciąga „Naczelnym u nas jest artystą“, O legendzie Fryderyka Chopina w literaturze polskiej); cílem příspěvku bylo poukázat na přítomnost - řekněme českých nebo s Čechami jednoznačně spojených míst či osob českého původu vstupujících do života skladatele a na způsob jejich zpracování v beletristické, tedy umělecké, nikoli dokumentární životopisné nebo vědecké podobě - ta nám pouze posloužila jako pozadí ke komparaci historické pravdy na jedné straně a umělecké fikce na straně druhé.

\section{References}

BARTOS, O. (ed.). 1974. Slovnik spisovatelu. Polsko. Praha: Odeon.

BEDNAR, K. 1961. Chopin v Marianskych Laznich. Marianske Lazne: Spolecnost Fryderyka Chopina.

BEDNAR, K. 1981. Fryderyk a Marianna. Chopin v Marianských Laznich. Praha Marianske Lazně: Supraphon.

BERGER, W. A. 1995. Marienbad. Ostrava: nákladem autora.

BERGER, W. A. 1996. Marienbad a jiné povídky. In: edice Tvary: príloha casopisu Tvar, n. 18; prel. Erich Sojka. ISSN 0862-657 X

BRANISLAV, F. 1964. Divertimento a kantilena. Praha: Ceskoslovensky spisovatel.

BROSZKIEWICZ, J. 1967. Kształt miłości. Warszawa: Czytelnik.

BROSZKIEWICZ, J. 1976. Podoba lasky. Prel. Richard Vyhlidal. Praha: Svoboda.

DUSZNIKI-Zdrój. 2014. [online] (cit. 23. 9. 2014) <http://cs.wikipedia.org/wiki/ Duszniki-Zdrój>.

ERBOVA, K. 2003. Jiz nikdy nedovolim pozaru - Już nigdy pożarem mi nie płonąć. Prel. Jan Pyszko. Tisnov: Sursum. ISBN 80-7323-037-2

GOETHE, J. W. 1999. Utrpeni mladeho Werthera. Prel. Erik Adolf Saudek. Praha: Aurora. ISBN 80-85974-61-4

${ }^{1}$ Podrobněji o hudebních inspiracích v poezii polských básníků českého Těšínska viz Martinek, 2012: 180-199. 
CHOPIN, F. 1961. Listy rodine a prstelum. Prel. Jaroslav Simonides a Kamil Bednar. Praha: Statni hudebni vydavatelstvi.

IWASZKIEWICZ, J. 1955. Chopin. Krakow: Polskie Wydawnictwo Muzyczne.

IWASZKIEWICZ, J. 1957. Fryderyk Chopin (1810 - 1849). Prel. Jaroslav Simonides. Praha: SNKLHU.

JASICZEK, H. 1952. Pochwała życia. Cesky Tesin: Wydawnictwo SLA JASICZEK, H. 1959. Jaśminowe noce. Cesky Tesin: Wydawnictwo SLA.

JAWORCZAKOWA, M. 1968. Własna melodia. In: Stanisław Aleksandrzak, Marian Wadecki, Przez stulecia. Opowiadania z historii Polski. Warszawa: Nasza Księgarnia, pp. 391-394.

KADEN-BANDROWSKI, J. 1938. Życie Chopina. Warszawa: Gebethner i Wolff.

KAREN, J. 1979. Hledaní modreho tonu. Praha: Melantrich.

KLAPPER, O. (ed.). 1975. Chopin v Cechach 1835. Marianske Lazne: Spolecnost Fryderyka Chopina.

KLAPPER, O. (ed.). 1983. Zde zni ozvena jeho tonu. Marianske Lazne: Spolecnost Fryderyka Chopina.

KUBSKI, B. - KUBSKI, J. 1962. Wypisy dla klasy VII. Warszawa: Państwowe Zakłady Wydawnictw Szkolnych.

KUNCEWICZOWA, M. 1932. Kurgast Marienbadzki. In: Kurier Warszawski, n. 272/2, pp. X.

KUNCEWICZOWA, M. 1937. Miłość Chopina. In: Sygnały, n. 1, pp. 7.

KUNCEWICZOWA, M. 1975. Odkrycie Patusanu. Warszawa: Instytut Wydawniczy PAX, 1983.

LISSA, Z. 1944. Fryderyk Szopen. Krótki życiorys. Moskwa: Związek Patrjotów Polskich w ZSSR.

LISSA, Z. 1970. Studia nad twórczością Fryderyka Chopina. Kraków: PWM.

LISSA, Z. 1975. Nowe szkice z estetyki muzycznej. Kraków: PWM.

LISSA, Z. 1982. Nove studie z hudebni estetiky. Prel. Jindrich Brucek. Praha: Editio Supraphon.

ŁOPALEWSKI, T. 1975. Fryderyk. Lublin: Wydawnictwo Lubelskie. ISBN 9780231064064

ŁOPALEWSKI, T. 1986. Fryderyk. Prel. Josef Zumr. Praha: Albatros.

MACIĄG, K. 2010. „Naczelnym u nas jest artystą.“ O legendzie Fryderyka Chopina w literaturze polskiej. Rzeszów: Wydawnictwo Uniwersytetu Rzeszowskiego. ISBN 9788373384996

MARTINEK, L. 2012. Związki literatury i muzyki w utworach pisarzy cieszyńskich Henryka Jasiczka, Adolfa Dostala i Jana Pyszki. In: Acta Universitas Lodziensis. Folia Litteraria Polonica, č. 1, Muzyka i muzyczność w literaturze od Młodej Polski do czasów najnowszych (I). Łódź: Primum Verbum, pp. 180-199. ISSN 1505-9057

MARTINEK, L. 2013. Fryderyk Chopin v ceske literature. Opava: Slezská univerzita. ISBN 978-80-7248-802-5

MAREŠ, V. 1993. Ruze pro Fryderyka. Marianske Lazne: Spolecnost Fryderyka Chopina - Kulturni a spolecenske stredisko v Marianských Laznich.

MARES, V. 2000. Brilantni valcik. Navstevy Fryderyka Chopina v Cechach. Praha: Dar Ibn Rushd. ISBN 80-86149-18-8

NORWID, C. K. 1983. Chopinuv klavir. Prel. Jan Pilar. Praha: Odeon

OSOBY zviazane z Chopinem - Juliusz Kaden-Bandrowski. [online] (cit. 23. 9. 2014)

< http://pl.chopin.nifc.pl/chopin/persons/bibliography/id/2507>.

PABJAN, B. The reception of Chopin and his music in Polish society. In: International Review of the Aesthetics and Sociology of Music, 2010, n. 41 (2), pp. 343-378. ISSN 0351-5796

PÁVEK, J. 1976. Chopiniana. Praha: Lyra Pragensis.

PRZECZEK, W. 1990. Notatnik liryczny. Warszawa: Staromiejski Dom Kultury. 
PRZECZEK, W. 1998. Intimni bedekr. Prel. Libor Martinek. Cesky Tesin: Olza. ISBN 80-86082-09-1

PYSZKO, J. 1993. Słowa jak kamienie. Warszawa. ISBN83-85136-40-1

SAND, G. 1983. Psaní o lásce. Z francouzského originálu George Sand, Correspondance, Paris, Garnier Frères, Tome IV. „A Adalbert Grzymala (Nohant, fin mai 1838)" prel. a poznamku napsal Jaroslav Simonides. Praha: Supraphon

SIERPIŃSKI, Z. 1959. Warszawa pana Fryderyka. In: Nowe Książki, n. 23, pp. 14241425.

SIKORA, W. 1997. Svatky v Marianskych Laznich. In: Obratnik, n. 16, pp. 22; prel. Libor Martinek. ISSN 1801-8688

SIKORA, W. 1999. Svatky v Marianskych Laznich. In: Literární noviny, n. 47, pp. 14; prel. Libor Martinek. ISSN 1210-0021

SIKORA, W. 2002. Husty zivot byval - Gęste było życie. Prel. Libor Martinek et al. Česky Tesin.

SIMONIDES, J. 1953. Praha je mesto vcelku pekne. Marianske Lazne: Spolecnost Fryderyka Chopina - Kulturni a spolecenske stredisko mesta Marianskych Lazni.

SIMONIDES, J. 1981. Doslov. In: Kamil Bednar: Fryderyk a Marianna (Chopin v Marianskych Laznich). Praha - Marianske Lazne: Supraphon.

SIWKOWSKA, J. 1959. Tam, gdzie Chopin chodził na pół czarnej... Stylizacje. Warszawa: Książka i Wiedza.

SIWKOWSKA, J. 1969. Pan Chopin opuszcza Warszawę. Warszawa: Książka i Wiedza.

SIWKOWSKA, J. 1986, 1988, 1996. Nokturn czyli rodzina Fryderyka Chopina i Warszawa w latach 1832 - 1881. Sv. 1 - 3. Warszawa: Książka i Wiedza. 1986 ISBN neuvedeno; 1988 ISBN neuvedeno; 1996 ISBN 8305127974

STEPAN, L. (ed.). 2000. Slovnik polskych spisovatelu. Praha: Libri. ISBN 80-7277005-5

TARASTI, E. 1992. A narrative grammar of Chopin's G minor Ballade. In: Minds and Machines, Journal for Artificial Intelligence, Philosophy and Cognitive Science, n. 2 (4), pp. 401-426. ISSN 0924-6495

TOMASKOVA, M (ed.). 1989. Milostna sonata. George Sandova a Fryderyk Chopin v dopisech. Prel. Milena Tomaskova. Praha: Odeon. ISBN 80-207-0085-4

WODZIŃSKA-KOŚCIELSKA, J. 1973. Fryderyk Chopin v Marianskych Laznich roku 1836. Prel. Jaroslav Simonides. Marianské Lazne:Spolecnost Fryderyka Chopina. ZEMEK, O. 1967. Chopinovske akordy. Cyklus basni. Praha - Marianske Lazne: Polské kulturni stredisko - Spolecnost Fryderyka Chopina

ZIEMIĘCKA, E. 1861. Wspomienie. In: Noworocznik Ilustrowany dla Polek. Noworocznik 1862, Warszawa: s. n., s. 1-8.

ZIEMIĘCKA, E. 1974. Vzpominka na Chopina. Prel. Jaroslav Simonides. Praha Marianské Lazne: Supraphon.

Words: 7168

Characters: 49547 (27,53 standard pages)

Assoc. Prof. Dr. Libor Martinek, PhD.

Institute of the Czech Language and Library Science

Faculty of Philosophy and Science in Opava

Silesian University

Masaryk street 343/37

74601 Opava

Czech Republic

martinek.libor@centrum.cz. 